\title{
THE VILLAGE STUDIES PROJECT BIBLIOGRAPHICAL PROGRAMME
}

\author{
C.M. Lambert*
}

Three major bibliographical exercises have been carried out concurrently with other research of the Village Studies Programmc (VSP). The largest of these is the compilation of a General Bibliography of Village Studies, a record of village surveys completed since 1950 in LDCs. The second is the Bibliography on Labour Utilisation which complements a VSP report to the ILO on Village Labour Situations. The third is a Bibliography on Village Nutrition Studies, an integral part of the research into village level nutrition needs sponsored by the Freedom from Hunger Campaign, (outlined in S. Schofield's paper in this issue).

General Bibliography of Village Studies

The 'sine qua non' of the whole VSP is the large collection of hitherto largely neglected primary, village-level data that has been assembled for the various research programmes being carried out at the IDS. One of the first tasks confronting the initiators of the Programme was to approach personally as many people in research and other institutes in LDCs to ascertain the nature of village-level research actually being carried out, and to request copies of the results. Five main field-trips have been made, and a very large number of contacts established in Asia, Africa and Latin America. Hence many unpublished and otherwise little known village studies have been brought together, and a flow of subsequent material encouraged. The major contacts in India were the nine AgroEconomic Research Centres from which nearly 200 village surveys have been obtained. Although a few are published monographs, most are unpublished mimeographed reports, and in some cases copies have been made for our purposes. The main African series come from the various O.R.S.T.O.M. centres throughout Francophone Africa and as a result nearly half the 200 African village surveys come from French sources. The Latin American material has presented the most difficulties: firstly, to ensure adequate coverage of the likely

* Claire Lambert has been doing research and bibliographic work in The Village Studies Programme at IDS since 1971. 
resource centres; secondly, to achieve reliable contacts from which to guarantee a flow of relevant documents; thirdly, because "village studies' are not always appropriate to the Latin American social organisation; and, finally, because the analysis of the Spanish material has meant additional staff and research problems. Despite all these limitations, however, there are now about 200 Latin American village studies on record.

In addition to the material resulting from field-trips and other contact-building abroad, published material has been searched, and a card index of village studies has been maintained, which now includes over 2000 references to books, monographs, journal articles, theses and unpublished material. French, German and Spanish material is included as far as possible.

The analysis of the data included in the studies constituted another major exercise. Although must of the material was available at the IDS, many items have had to be especially acquired, and we are grateful to all the library staff, at the IDS, and the University, who have enabled us to do this. A large number of research assistants have been recruited to assist in the reading and data recording for this part of the programme.

For each study, we have prepared (a) bibliographical and methodological information, (b) a listing of basic village data (location, population, land areas, amenities, demographic structure, occupational patterns, labour utilisation, land ownership and operation, income and expenditure patterns, agricultural techniques, educational levels, food consumption etc.) (c) a guide to the measurement, presence or absence of information on numerous contingent village realities, (d) a brief summary and evaluation of the survey. All this was first recorded onto prepared bibliographical sheets, and subsequently coded. This exercise is now virtually complete and preparations are now under way for publication by Frank Cass \& Co., London. Sections (b) and (c) above are being punch-carded for each village based on the coding sheets. These sections will be computer-produced. An example of an entry for publication is given at the end of this article together with some explanatory comments.

The first volume will be devoted entirely to India and will include about 1200 entries arranged State-wise. There will also be a general introductory article and evaluation of the data by VSP members. The 
index will be a select Topics Index (listing all villages with, for example, data on irrigation, migration, land-use or education) and will also be computer-produced from the data stored on punched cards. A second volume to appear later will cover other Asian countries, Africa and Latin America.

\section{Labour Utilisation: A Bibliography of Village Studies}

Although the General Bibliography includes information on labour utilisation, this special bibliography makes a more detailed analysis of the 500 or so relevant village studies. It complements a report to ILO: Assessing Village Labour Situations in Developing Countries (J. Connell and M. Lipton, IDS, 1973). Each entry, arranged alphabetically by country, includes a short general comment on the village followed by a brief evaluation of the labour data and a column of comprehensive coded labour information. Ultimately the final bibliography (now complete in two volumes, India and Other Countries) will be published; mimeographed copies are available from the VSP office at the IDS.

\section{Nutrition Bibliographies}

Six annotated Nutrition Bibliographies on Africa, Latin America, India, S.E. Asia, Middle East and Oceania have been compiled by $S$. Schofield in the course of her nutrition research within the VSP. In all about 470 nutrition/health-specific surveys providing data for 870 villages have been retrieved and the majority of these are available at the IDS. A revised edition of each section is now being produced, and they will also be published by Cass, probably together with a nutrition monograph based on the VSP research.

These then constitute the main bibliographical output of the VSP. Despite the shortcomings and limitations, the collection of village surveys now assembled at the IDS is unique. Through the various bibliographies we hope that many people and research centres will be aware of the large amount of village-level data available and that this will promote requests for such material to be directed through the IDS. Important bibliographical objectives in the next phase of the VSP are to relate the village-study material to other relevant collections, notably farm-management data, in the field of rural development; to update our collection; to provide maximum access if possible by placing copies of the collection in regional libraries, to 
Third World Scholars; and to use our bibliography to pinpoint gaps in village-level knowledge.

Sample entry for the Gencral Bibliography of Village Studies.

\section{INDIA / MADHYA PRADESH}

AGRO-ECONOMIC RESEARCH CENTRE FOR MADHYA PRADESH (Jabalpur)

Of the 24 village studies carried out between 1962 and 1970,21 are available at the IDS. They fall into two groups. Those on tribal villages (nos. 4,8,10,22,24) contain detailed, though largely non-quantifiable, data with a strong anthropological bias. Those on non-tribal villages include much tabulated data, though quality and presentation vary. Included in the latter group are data on demography, occupations, household budgeting, land holdings and land utilization, agricultural practices and marketing systems. Labour input data for specific occupations are included in some cases. No village re-surveys have been carried out.

Indian village studies, no. 1 -

Gwalior (later Jabalpur), 1962 -

1. Rural Bhopal: a comparative study of four villages, by C.

Muthiah. 1962 p. 213.

The impact of a Heavy Electricals Plant close to the villages was found to have been minimal as far as the economy was concerned. Data are of ten aggregated.

\begin{tabular}{|c|c|c|c|c|c|c|c|c|c|}
\hline $\begin{array}{lc}\text { ORIENT } \\
1 & -\end{array}$ & $\begin{array}{|cc|}\text { STDY T } \\
4 & - \\
\end{array}$ & 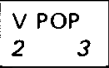 & \begin{tabular}{|lr|}
\multicolumn{2}{|l|}{ TOWN } \\
3 & 6 \\
\end{tabular} & \begin{tabular}{|l|}
$\mathrm{RD} R \mathrm{RL}$ \\
1
\end{tabular} & $\mid \begin{array}{ccc}M-L & R T \\
8 & 1 & -\end{array}$ & \begin{tabular}{|lll} 
IRRIG \\
3 & 3 & - \\
\end{tabular} & \begin{tabular}{|l|}
$R N F L L$ \\
10
\end{tabular} & $\begin{array}{lr}\text { TERRN } \\
8 \quad-\end{array}$ & \begin{tabular}{|l} 
PROD 1 \\
29 \\
29
\end{tabular} \\
\hline $\begin{array}{l}\text { PROD } 2 \\
-\quad-\end{array}$ & $\mid \begin{array}{c}\text { CSH PR } \\
29\end{array}$ & $\begin{array}{c}\text { AG SYS } \\
3\end{array}$ & $\begin{array}{c}\text { CULT T } \\
2\end{array}$ & \begin{tabular}{|cc} 
TENURE \\
1 & 2
\end{tabular} & $\begin{array}{lc}\text { LAN RL } \\
-\quad 6\end{array}$ & $\begin{array}{l}\text { FLD YR } \\
11\end{array}$ & 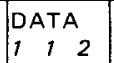 & $\begin{array}{cc}\text { METHOD } \\
1\end{array}$ & $\begin{array}{l}\text { FLDWRK } \\
1--\end{array}$ \\
\hline $\begin{array}{cc}\mathrm{SCHOOL} \\
1 & -\end{array}$ & $\mid \begin{array}{c}\text { COMM } \\
-\quad 1-\end{array}$ & $\begin{array}{l}\text { DEMOG } \\
1--\end{array}$ & $\begin{array}{cc}\text { HSEHLD } \\
0 & 0\end{array}$ & 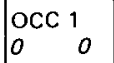 & $\mid \begin{array}{ll}\operatorname{Orcc} & 2 \\
0 & 0\end{array}$ & $\begin{array}{l}\text { LABOUR } \\
112\end{array}$ & $\mid \begin{array}{l}\text { AG INP } \\
0 \\
0\end{array} 1$ & 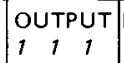 & $\begin{array}{l}\text { MARKET } \\
1-1\end{array}$ \\
\hline $\mid \begin{array}{lc}\text { INCOME } \\
2 & 2\end{array}$ & $\left|\begin{array}{ccc}\text { ASSETS } \\
1 & 0 & -\end{array}\right|$ & $\begin{array}{l}\text { GOODS } \\
01\end{array}$ & $\begin{array}{l}\text { LV STD } \\
0-1\end{array}$ & $\mid \begin{array}{ccc}\text { LAND } & 1 \\
1 & 1 & 0\end{array}$ & $\begin{array}{lr}\text { CROPS } \\
7\end{array}$ & $\begin{array}{l}\text { AG TEC } \\
0,1-\end{array}$ & $\begin{array}{lll}\text { MIGR P } \\
1 & 2 & -\end{array}$ & $\begin{array}{ll}\text { EDUC } \\
2\end{array}$ & \begin{tabular}{|lr} 
ATTDS \\
1 & 1
\end{tabular} \\
\hline $\begin{array}{ll}1143 & \mathrm{~K} \\
1144 & \mathrm{M} \\
1145 & \mathrm{~B}\end{array}$ & $\begin{array}{l}\text { lisrod } \\
\text { awariya }\end{array}$ & canta & & & & & & & \\
\hline
\end{tabular}


Explanatory Notes on the method of documentation used in the General Bibliography of Village Studies

Each of the main series will be preceeded by a brief evaluatory comment indicating in general the range of material included, its presentation and reliability. Each of the abbreviated headings given in the coded section covers an important aspect of the data and each of the numbers indicates what kind of data is present. For example, the number ' 1 ' for ORIENT means that the general orientation of the study is socio-economic; the number ' 4 ' in the following box means that the type of study (STDY T) is comparative, and so on for the other basic features, population and village type (V POP), proximity to town and town size (TOWN), man-land ratios for the whole village area, the net and gross cropped areas (M-L RT), etc. Fieldwork, data analysis and methodological aspects are included under the four sections Fieldwork Year (FLD YR), data coverage and quality (DATA), methods of survey, ie.e census, observation, written records etc. (METHOD) and numbers of fieldworkers, residence in the village and the time spent in the field under Fieldwork techniques (FLDWRK). Quantifiable data on occupational structure, both primary and secondary by sector and function is included in the study and is indicated by 'O's under the headings for occupation (OCC 1 and OCC 2). The kind of data given whether quantifiable for the whole village or for groups, or purely descriptive is also indicated, for other topics such as labour utilisation (LABOUR) ownership and operation of land (LAND), cropping patterns (CROPS), agricultural techniques including mechanization (AG TEC), migration permanent and temporary, education and literacy, attitudes on social and economic issues. Although the technical details have not yet been fully worked out it is envisaged that a key from which information is readily translatable will be included as a bookmark in the final bibliography. 